\title{
Identification and prioritization of areas with high environmental risk in Mediterranean coastal areas: A flexible approach
}

\author{
Michela Marignani a,b,*, Daniele Bruschi ${ }^{\text {a }}$, Davide Astiaso Garcia ${ }^{a}$, Raffaella Frondoni a ${ }^{\text {, Emanuela Carli }}{ }^{\text {a }}$, \\ Maria Silvia Pinna ${ }^{\mathrm{a}, \mathrm{b}}$, Fabrizio Cumo ${ }^{\mathrm{a}}$, Franco Gugliermetti ${ }^{\mathrm{a}}$, Arne Saatkamp ${ }^{\mathrm{c}}$, Aggeliki Doxa ${ }^{\mathrm{c}}$, \\ Emi Martín Queller ${ }^{c}$, Mohamed Chaieb ${ }^{\mathrm{d}}$, Magda Bou Dagher-Kharrat ${ }^{\mathrm{e}}$, Rana El Zein ${ }^{\mathrm{e}}$, Sarah El Jeitani ${ }^{\mathrm{e}}$, \\ Carla Khater ${ }^{\mathrm{f}}$, Sophie Mansour ${ }^{\mathrm{f}}$, Anwar Al-Shami ${ }^{\mathrm{g}}$, Ghinwa Harik ${ }^{\mathrm{g}}$, Ibrahim Alameddine ${ }^{\mathrm{g}}$, \\ Mutasem el-Fadel $^{\mathrm{g}}$, Carlo Blasi ${ }^{\mathrm{a}}$ \\ a Sapienza University of Rome, Piazzale Aldo Moro 5, 00185 Rome, Italy \\ b University of Cagliari, DISVA, Viale S. Ignazio 13, 09123 Cagliari, Italy

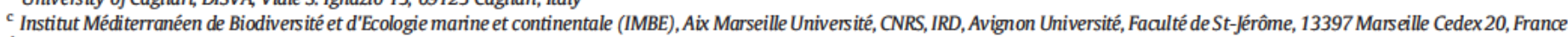 \\ ${ }^{d}$ University of Sfax, Research Unit in Plant Biodiversity and Ecosystem Dynamics in Arid Environment (BIOECOS-MA), Route Soukra km 3.5 BP n 1171,3000 Sfax, Tunisia \\ e Saint Joseph University, Laboratoire Caractérisation Génomique des Plantes, Rue de Damas BP 17-5208 Mar Mikhaël, 11042020 Beirut, Lebanon \\ ${ }^{\mathrm{f}}$ National Council for Scientific Research Lebanon, P.O. Box 11-8281, Ryad El Solh, 11072260 Beirut, Lebanon \\ ${ }^{g}$ American University of Beirut, Department of Civil and Environmental Engineering, P.O Box 11-0236, Riad El Solh, 11072020 Beirut, Lebanon
}

\section{H I G H L I G H T S}

- Respond to the need of an interdisciplin ary management of coastal ecosystems

- Biosphere, lithosphere and anthro posphere data were considered, com bined in a prioritization procedure

- A set of criteria for prioritizing sites main ly based on plant diversity in response to oil spill, fragmentation and HNS

- Different areas were prioritized for each hazard, the response of habitat and hab itat and species were highly correlated

- This approach can provide public admin istrations and local communities an easy to use instrument towards ICZM

\section{A R T I C L E I N F O}

\section{Article history:}

Received 21 December 2016

Received in revised form 26 February 2017

Accepted 27 February 2017

Available online 8 March 2017

Editor: D. Barcelo
G R A P H I C A L A B S T R A C T

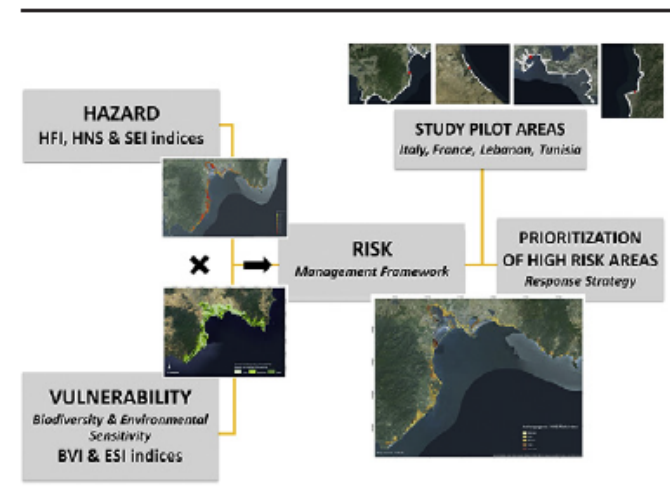

\footnotetext{
* Corresponding author at: University of Cagliari, DISVA, Viale S. Ignazio 13, 09123 Cagliari, Italy.

E-mail addresses: marignani@unica.it (M. Marignani), daniele.bruschi@uniroma1.it(D. Bruschi), davide.astiasogarcia@uniroma1.it (D. Astiaso Garcia), raffaella.frondoni@uniroma1.it (R. Frondoni), emanuela.carli@uniroma1 it (E. Carli), m.silviapinna@gmail.com (M.S. Pinna), fabrizio.cumo@uniroma1 it (F. Cumo), franco.gugliermetti@uniroma1.it (F. Gugliermetti), ame.saatkamp@imbe.fr (A. Saatkamp), aggeliki.doxa@imbe.fr (A. Doxa), emilia.queller@imbe.fr (E.M. Queller), magda.boudagher@usj.edu.lb (M. Bou Dagher-Kharrat), sarah.jeitani@net.usj.edu.lb (S. El Jeitani), age08@aub.edu,lb (A. Al-Shami), ghx00@aub.edu,lb (G. Harik), ibrahim.alameddine@aub.edu,lb (I. Alameddine), mfadel@aub.edu,lb (M. el-Fadel), carlo.blasi@uniroma1,it (C. Blasi).
} 
Keywords:

Hazard analysis

Plant diversity

Risk assessment

Habitat fragmentation

GREAT Med project use approach to locate and prioritize the areas more susceptible to those stressors, in order to have a practical in strument for risk management in the ordinary and extra ordinary management of the coastline. The procedure has been applied at pilot areas in four Mediterranean countries (Italy, France, Lebanon and Tunisia). This ap proach can provide policy planners, decision makers and local communities an easy to use instrument able to facilitate the implementation of the ICZM (Integrated Coastal Zone Management) process in their territory.

\section{Introduction}

The Mediterranean Basin constitutes one of 200 ecological regions with the highest level of biodiversity in the world (Olson and Dinerstein, 1998). Although covering only $0.8 \%$ of the world's sea sur face and $0.3 \%$ of its seawater volume, the Mediterranean Sea is home to 10,000 to 17,000 marine species, $20 \%$ of which are endemic (Bazairi et al., 2010; Coll et al., 2010). The terrestrial plant diversity of the Basin is similarly rich, with about 25,000 species native to the region (60\% of them are Mediterranean endemics, half of which corresponds to narrow endemics; Thompson, 2005), and around $10 \%$ of the world's higher plants concentrated in an area covering $<2 \%$ of the land mass (Medail and Quezel, 1999). Therefore, the Mediterranean Basin is also recognized as one of 34 Global Biodiversity Hotspots (Mittermeier et al., 2005; Myers et al., 2000).

According to the IUCN (IUCN, 2016), the major causes of threat to Mediterranean species include, by order of importance, habitat loss and degradation, pollution and over exploitation of natural resources (Cuttelod et al., 2008). Moreover, urbanization, tourism and industrial development are the main drivers of land cover change (Benoit and Comeau, 2005; European Environment Agency, 2013). It is estimated that the number of people living permanently in the Mediterranean coastal regions will increase by $1.4 \%$ per annum along the Southern and Eastern shorelines, reaching 108 million by 2025; while the North ern shorelines are expected to stabilize at about 68 million (Coudert and Larid, 2006). These increases are predicted to cause the loss of $200 \mathrm{~km}$ per year of coastline to urban areas between the present and 2025 . The Mediterranean Basin is also one of the world's busiest areas for mar itime traffic with 200,000 commercial ships crossing annually the sea and approximately $30 \%$ of international sea borne volume originating from its ports or directed towards them (Abdulla and Linden, 2008). Tourism and freight transport, offshore platforms and waste discharges from boats or affluent rivers are an additional important pollution source for the semi enclosed sea (Lejeusne et al., 2010; Cózar et al., 2015). The request for an easy and efficient application of ICZM to the Mediterranean Basin remains very relevant (Buono et al., 2015; Prem, 2010). This is especially true when considering also that the overall re sponse capability of many Mediterranean countries (Italy, Greece, Malta, Spain) to deal with Hazardous and Noxious Substances (HNS) in cidents was still rather limited few years ago (EMSA, 2013).

Historically, engineers were the main party in charge of the manage ment of coasts, because management was essentially focused on coastal projects that consisted of infrastructure design and construction to en hance the exploitation, or the physical protection of the coastal area (Kamphuis, 2011). As such, several instruments for the assessment of vulnerability and hazard have been developed, especially in the engi neering literature (Appelquist and Balstrøm, 2015; Komendantova et al., 2014) with limited studies focusing on the assessment of the concept of risk and hazard considering the ecological implications (see for a re view De Lange et al., 2010). More recently, the definitions of coastal management and engineering have been extended with interdisciplin arity and transdisciplinarity evolving to become the cornerstone for the future management of coastal ecosystems (Kamphuis, 2011; Stock and Burton, 2011). In fact, decision makers have started to feel that "simple solutions to complex problems" is not the key towards the suc cessful management of a territory (Jackson, 2006; Reyers et al., 2010). As a consequence, both the scientific communities and funding agencies are refocusing their efforts towards integrating the research outcomes from multidisciplinary research, trying to break down barriers that often prevent our shared understandings of complex issues (Jackson, 2006; Stock and Burton, 2011). Similarly, the concept of prioritization of sites has been widely examined for biodiversity conservation (e.g. Pressey et al., 1993; Wilson et al., 2006), for public health implications in case of pollution (Harold et al., 2014) but only recently as an instru ment for the routine management of the territory (e.g. for harbors in Valdor et al., 2016).

Within this context, the GREAT Med project (Generating a Risk and Ecological Analysis Toolkit for the Mediterranean), funded by the ENPI CBC Med program of the European Union, aims to contribute to the de velopment of an interdisciplinary strategy for assessing plant diversity and the main human pressures in critical areas of the Mediterranean coasts, with a view towards conservation and monitoring of natural her itage. The specific objectives of the project include the development of an accessible and understandable procedure for assessing coastal plant diversity and its vulnerability to potential stressors (such as oil spills, fragmentation of natural habitats), and the definition of an easy to use approach to locate and prioritize the more susceptible areas. This would provide a practical instrument for risk management in the ordi nary and extra ordinary management of the coastline. The project in volves several pilot areas in four Mediterranean countries from different sides of the Mediterranean Basin (Italy, France, Lebanon and Tunisia), an engagement deemed crucial for setting up effective and standardized descriptors, criteria and indicators that take into account different ecological and socio economic contexts. The objective of our planning was to create a methodological framework that can be used and adapted to diverse situations, i.e. different knowledge of the biodi versity of the local area, different types of threats/pressure, different socio economic situation, different objectives of prioritization (for in stance for biodiversity conservation, tourism development, oil spill emergencies).

We present a flexible and adaptable methodological approach to i) assess environmental risk in coastal areas and, accordingly, ii) prioritize the areas more prone to suffer from one (or more) selected risks.

\section{Material and methods}

\subsection{Pilot areas}

The project implemented its activities in four pilot areas in the Med iterranean basin, which are characterized by high levels of biodiversity and economic development. Each pilot area comprises at least $60 \mathrm{~km}$ of coastline that is meant to cover the broad scale extension of the as sessment in which 11 sites were selected to address the local scale (small extension, Fig. 1). The selection process encompassed the main types of land use/cover, environmental characteristics, and main types of human pressures present in the whole Mediterranean basin. In par ticular, we focused on the presence of oil refineries, commercial port, Hazardous and Noxious Substances (HNS), and urban pressure.

Pilot Area 1 The Provence Alpes Côte d'Azur (PACA) region is at the southeastern coast of France. This region includes two National Parks, Calanques and Port Cros with terrestrial and marine protected areas and is limited to the west by the Camargue Regional Park. Tourism activities play a central role in the regional economy, with the PACA Re gion being the second most important touristic region in France. The 
France - Gulf of Provence
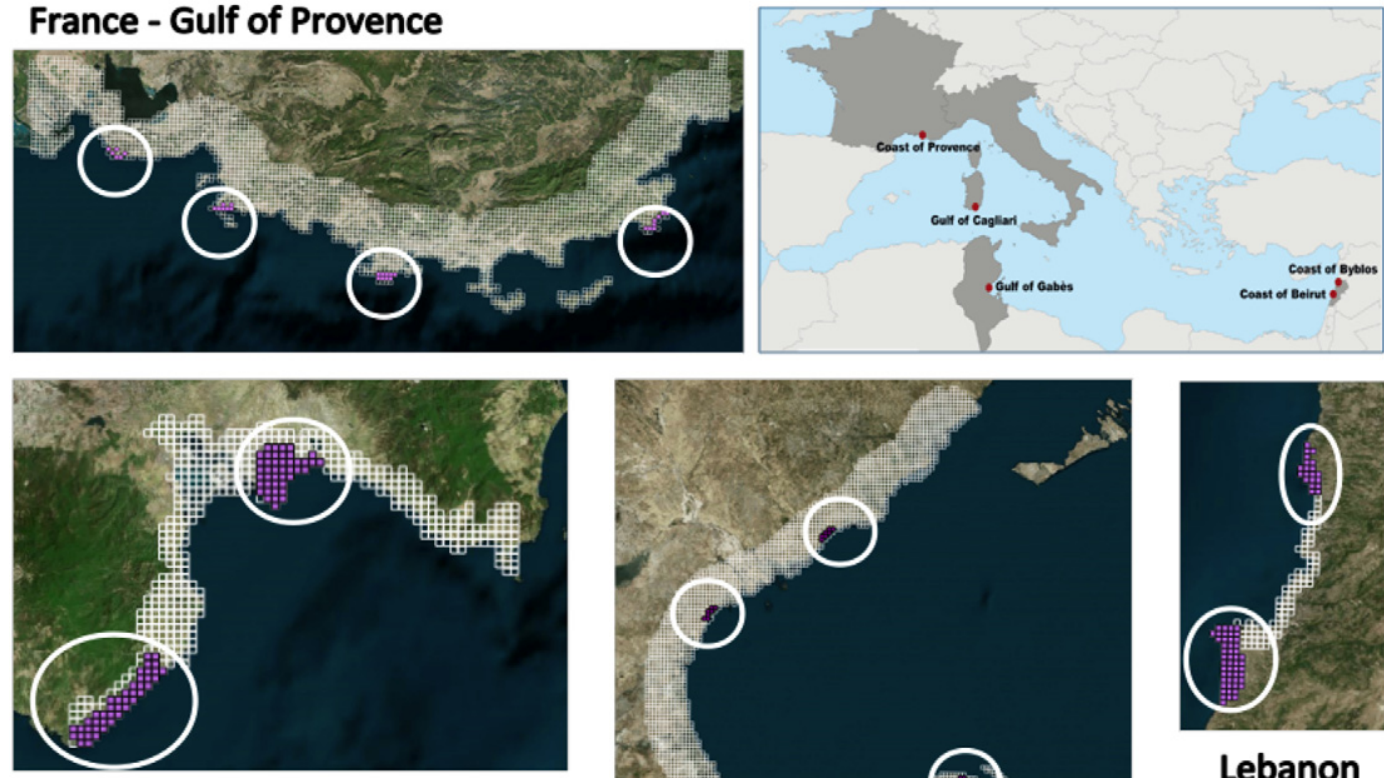

Italy - Gulf of Cagliari

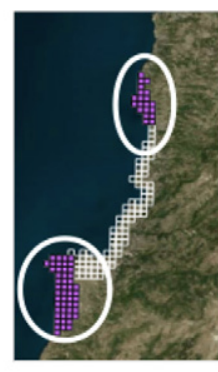

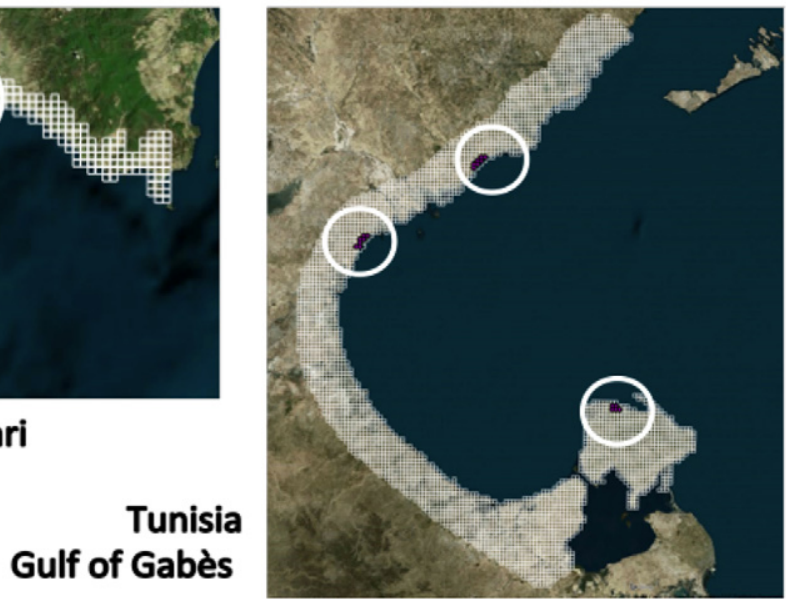

\section{Lebanon \\ Lebanon \\ coast}

Fig. 1. Location of the pilot areas in the four partner countries. Each pilot area is delimited by the white squared grid and it includes the study sites (white circles, purple grid).

area is home to four oil refineries and the port of Marseille, which is the largest in France and the fifth in Europe. In this pilot area, four study sites were selected along the coastal of the PACA region, which include several Habitat Directive sites (92/43/EEC).

Pilot Area 2 The Gulf of Cagliari in southern Sardinia includes hab itats of priority and community interest under the Habitats Directive (92/43/EEC) and two sites under the Ramsar Convention (UN Treaty Se ries No. 14583). The outstanding environmental and touristic value of the Gulf exists a short distance away from the city of Cagliari (> 150,000 people) and its major port, as well as with one of the largest re fineries in Europe (Sarroch). Along the Gulf of Cagliari two study sites were selected: Capo Sant'Elia Poetto Molentargius and the coastline stretching between the towns of Chia and Pula.

Pilot Area 3 The Gulf of Gabés in southern Tunisia is one of the coastal areas where tourism, increased urbanization and chemical in dustry (phosphate) carry the heaviest impact. The Gulf holds two major ports and is characterized by important salt marshes. Three study sites with different levels of human impact and development were selected: the island of Djerba and the surroundings of both Sfax and Gabés cities.

Pilot Area 4 In Lebanon, the high demand for coastal lands coupled with poor enforcement of legislation led to uncontrolled urban develop ment along the coastline. The coast is also littered with illegal occupa tion (recreational projects, breakwaters and marinas) that prevents public access to the seafront. These changes are major causes of coastal hydrodynamic modifications, degradation, soil erosion and biodiversity loss. Byblos and Beirut coastal regions were selected as the two study sites in Lebanon. The first zone is eligible to be part of the upcoming net work of Marine Reserves in Lebanon, and the second one is character ized by being highly urbanized.

\subsection{Vulnerability, hazard, risk and prioritization: four linked concepts}

Vulnerability is defined as "the degree to which a system is suscep tible to, and unable to cope with, injury, damage or harm" (De Lange et al., 2010). It is a function of exposure, effect (potential impact, sensi tivity) and recovery (resilience or adaptive capacity). Several elements are normally considered in its assessment including: ecological or eco system, socio ecological and the use of expert judgment (De Lange et al., 2010). Wamsley et al. (2015) adopts the definition proposed by Füssel (2007), where vulnerability is defined according to the system being assessed, the attribute of concern, and the hazard (or the "threat", "stressors" or anything recognized as "a threatening event, or the prob ability of occurrence of a potentially damaging phenomenon within a given time period and area").

In the environmental studies, to assess the risk, defined as the prob ability of a harmful effect due to a given hazard and resulting conse quences (De Lange et al., 2010), considerations are given to ecological characteristics of the biological system potentially exposed. The results of an environmental risk assessment can be used to prioritize the coastal area according to the chances that one of multiple risks can happen. In fact, hazard and vulnerability are closely linked to the topic of schedul ing of management as well as conservation action and the consecutive selection and prioritization of sites. When prioritizing, a temporal di mension is added to the ordinary management of the territory: it means to fix a time for and plan in advance where the interventions will go first in case of an emergency and where to direct our attention later. In the same way, we can prioritize to schedule the possible actions on a territory in order to propose where conservation action will pro duce the best long term protection and conservation outcomes, consid ering that species, habitats and ecosystems can be compromised at rates that vary depending on the habitat type, location and management (Kukkala and Moilanen, 2013).

In this study, we used plant diversity (including plant species and plant assemblages, hereafter referred to as habitats) as an indicator for ecosystem vulnerability: we assumed that the greater the plant diversi ty, the greater the vulnerability of the location (De Lange et al., 2010). This is because coastal areas that are naturally heterogeneous are likely to be relatively rare along the highly urbanized Mediterranean coasts and representative of environmental conditions that are under threat 
(Bazairi et al., 2010; European Environment Agency, 2013). Moreover, in this context, the potential loss of plant species or habitats of concern is of high significance since largely irreplaceable (very low recovery and/or resilience, De Lange et al., 2010).

The variety and availability of biological data is a common limit for many studies that conduct biodiversity assessments (Marignani et al., 2014); during the vulnerability assessment, the greatest impediment for a consistent evaluation is the lack of biological data (De Lange et al., 2010). Diverse situations are encountered in the four countries encompassing the pilot areas. While in Italy, Lebanon and Tunisia pri mary data collected during the project implementation were used, in France existing databases were relied upon. To face the problem of the availability and the use of heterogeneous biological data we tested a two scale approach in terms of spatial extension and data types.

At the pilot area level (broad extension: PACA region, France; Gulf of Cagliari, Italy; coastal areas between Byblos and Beirut, Lebanon; Gulf of Gabès, Tunisia, see Fig. 1) we considered habitat data, which are gener ally more easily available; at the site level (small extension, see Fig. 1) we used both species and habitat data (for more details on the plant di versity assessment see the Supplementary material).

We adopted a multi scale approach for two main reasons: data con straints and theoretical issues. Undeniably finer resolution data and richer set of variables permit the conduction of more precise risk as sessments and more accurate management planning (Norton et al., 2016; De Lange et al., 2010). Nevertheless, as stated by Levin (1992), modeling at finer scales demands more detailed data in order to predict outcomes effectively, while at larger scales statistical patterns become more regular and the use of coarser proxies more rational. Bio diversity knowledge is scale dependent and when moving from coarser to finer spatial resolution, our knowledge shortfalls expand (Hortal et al., 2015).

For the hazard assessment we selected three main threat/pressure indicators: i) habitat loss and fragmentation due to urbanization ii) ex posure to Hazardous and Noxious Substances (HNS) and iii) exposure to oil spills (see Fig. 2). For the assessment of oil spills risk, we also used the morphology of shoreline to evaluate the sensitivity to pollution (for more details see Al Shami et al., 2017 and Supplementary material).

All spatial analyses were performed at pilot area (habitat only, broad extension) and at site level (habitat and species, small extension), using the GIS software Qgis and ArcGIS® 10.X ESRI.

\subsubsection{Assessing vulnerability: plant diversity and coastal morphology}

To quantify vulnerability, we used two synthetic spatial indices. The biological one refers to plant species and habitat types and is based on a common set of simple indicators: species richness, presence of species of conservation concern, diversity of natural habitats and cover of hab itat of conservation value. Species of conservation concern refer to spe cies of national or regional interest according to global, national and regional Red Lists (IUCN), international Conventions and Directives (Habitats Directive, Bern Convention, CITES), or judgment of local plant experts (for instance, for narrow endemics or species with re duced population size). For habitats we referred to international and na tional policies when available (e.g. Habitats Directive for Europe, 92/43/ $\mathrm{EEC}$ ), or to local expert judgment (for more information on the concept of concern for species and habitats, see Blasi et al., 2011; Rossi et al., 2013). Note that all plant and habitat indicators refer to a standard spa tial grid of $1 \times 1 \mathrm{~km}$ (100 ha). We adopted this size considering data availability in the pilot areas, time and money constraints; compared to other widely adopted spatial grids, e.g. $4 \mathrm{~km}^{2}$ for the IUCN red listing assessment (IUCN, 2016), a $1 \mathrm{~km}^{2}$ grain for biological data appeared as a good compromise, suggested also by the standard adopted in Europe for e.g. Habitats Directive (INSPIRE, Infrastructure for Spatial Information in Europe).

Besides existing data sources, for Italy, Lebanon and Tunisia data on plant species were collected through field surveys, with a sampling strategy designed to ensure at least one sample plot per habitat type within each grid cell. In France, plant species data were derived from the SILENE (System of Information and Localisation of native and inva sive species) georeferenced database compiled by the National Mediter ranean Botanical Conservatory (CBNMed). It contains $\sim 4.5$ million

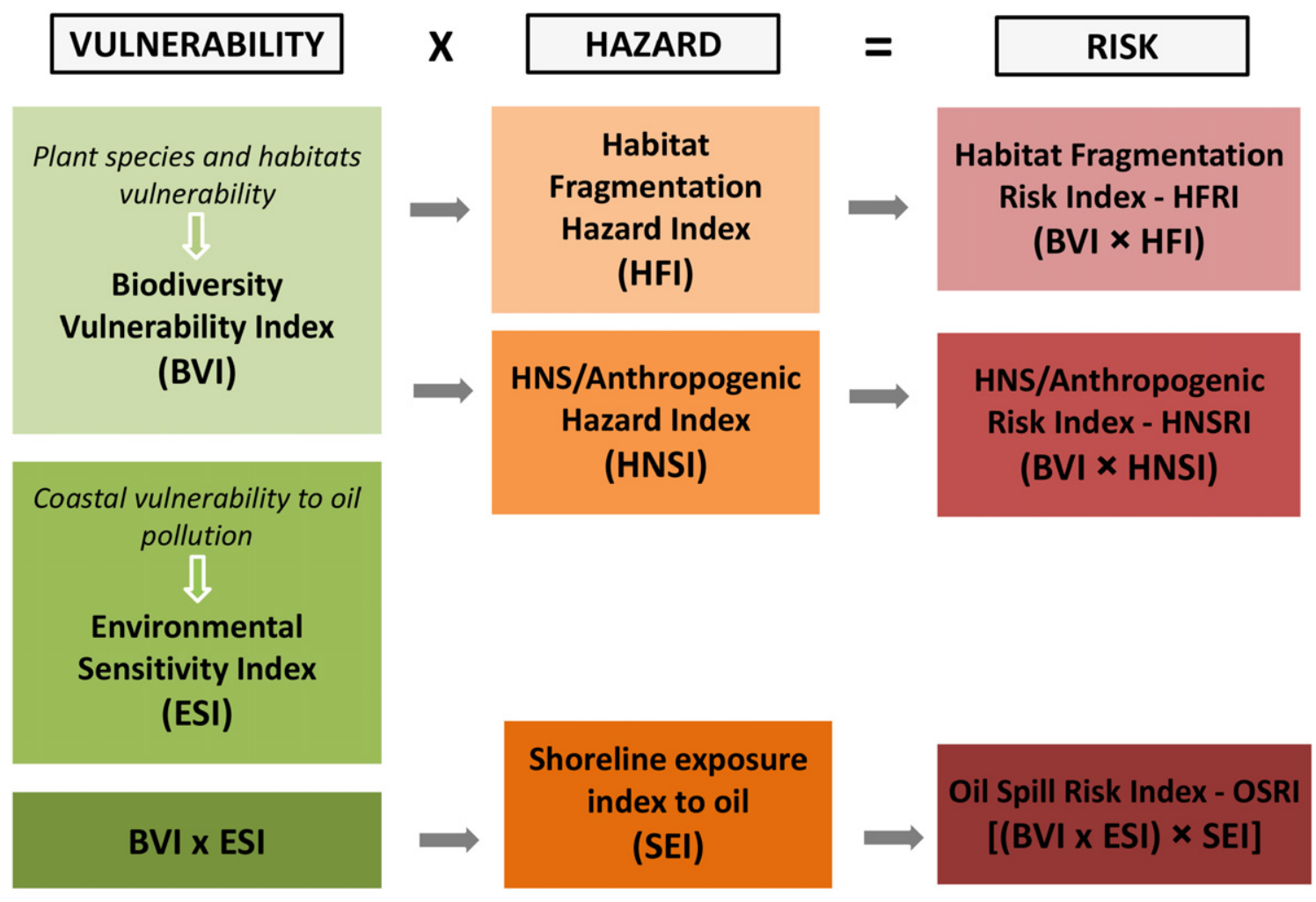

Fig. 2. Flowchart of the methodological approach. 
records on plant species occurrences in the French Mediterranean re gion (approx. $300 \mathrm{~km}$ coastline), which derived from different sources (herbaria specimen, field data, etc....).

Habitat data were derived from land cover maps at the regional or local scale available for each country, except for Tunisia, where original data were produced. For habitats of conservation value, France and Italy used also the habitat maps, available from the Natura 2000 network (Habitats Directive, Council Directive 92/43/EEC).

The complete use of indicators (habitat plus floristic data) covered the study sites because existing georeferenced data on plant occur rences are discontinuous over the whole pilot areas with resource con straints preventing the extension of field surveys over long coastal stretches. This restriction does not affect the flexibility of the approach and allows future data addition and refinements.

For each cell, the scores of each descriptor are ranked in three clas ses, from one (lowest value) to three (highest value). The classified values of all indicators are then summed up to obtain an overall score, which we called Biodiversity Vulnerability Index (BVI), with values ranging from four (when all individual values are one), to a maximum value of 12 (when all indicator values are three, see Supplementary ma terial). We used a classification that permits us to distinguish among low, medium and high risk and vulnerability levels, which is a common approach in risk assessments (see for instance Halpern et al., 2008; Arkema et al., 2013). Also Gauthier et al. (2010) recommended to use an impair number ( 3 or 5 classes) for the classification of species accord ing to the conservation priority. We chose an additive score method be cause it is relatively easy to create and teach, despite its cons (Hubbard and Evans, 2010).

The morphological index, or the Environmental Sensitivity Index (ESI), quantifies the sensitivity of the coastline to oil pollution. Shore lines are first classified in typologies according to a modified version of the NOAA coastline classification system (NOAA, 2002); classes are then ranked on the basis of their susceptibility to damage by oil spills, with lower rankings indicating lower vulnerability ( 0 lowest vulnerabil ity, 10 highest vulnerability). Shoreline classification criteria refer to a set of factors including relative exposure to wave and tidal energy, shoreline slope and substrate type (Al Shami et al., 2017 and Supple mentary material).

\subsubsection{Hazard analysis: urbanization and pollution}

The aim of the hazard analysis is to quantify potential and actual im pacts that can threaten the terrestrial plant diversity and the shoreline. In this context, fragmentation and habitat loss due to urbanization as well as oil and HNS pollution are recognized as main threats to coastal biodiversity in the Mediterranean (Cuttelod et al., 2008; Frondoni et al., 2011; Astiaso et al., 2013a; Lhotte et al., 2014; Malavasi et al., 2014) and as such were used to quantify the hazard through the devel opment of synthetic spatial hazard indices. To ensure harmonization of indicators across the four pilot areas, fragmentation was calculated based on the Global Land Cover for the year 2010 (National Geomatics Center of China, 2014). It was measured by a set of five landscape met rics that provide information on different aspects: the relative urban cover, the roads length, the mean and maximum patch size of natural and semi natural habitats and their total length of borders (McGarigal et al., 2002). All landscape metrics refer to a standard spatial grid of $1 \times 1 \mathrm{~km}$, calculated using a $3 \times 3 \mathrm{~km}$ moving window, to better reflect the isolation effect (e.g. in the case of a cell where land cover is mainly natural, but it is surrounded by cells where urban areas dominate). In the context of the quantification of urban pressure, we also used a floris tic indicator "richness in exotic species", since they represent a major threat to biodiversity worldwide and their occurrence is considered a good indicator for human pressures (Mack et al., 2000; Hejda et al., 2009). Due to differences in ecological requirements, habitat prefer ences and invasion dynamics between ancient and recent introductions, we opted to consider only neophytes (Pyšek et al., 2004, 2005; Celesti Grapow et al., 2009; Seebens et al., 2017). In fact, the response of archaeophytes to environmental factors is often similar to that of na tive species (Celesti Grapow et al., 2010). Data on the occurrence of ex otic plant species in each cell derived from field surveys and the literature.

The individual values of each indicator were ranked into three clas ses scored from one to three, with three representing the highest haz ard. All individual values were reclassified and then summed up to calculate an overall score, which represents the Habitat Fragmentation Index (HFI) ranging from 6 (low impact) to 18 (high impact) ${ }^{1}$ (see Sup plementary material for details).

As for the impacts of pollution on terrestrial plant diversity, we con sidered the effects of anthropogenic pollution sources, hazardous and noxious substances (HNS) and hydrocarbons (Al Shami et al., 2017). In dices were calculated only for grid cells that are located along the coast line (Astiaso Garcia et al., 2013c). All other cells were assigned a value of zero. Shoreline hazards associated with non oil pollution threats were assessed for all four study areas (Al Shami et al., 2017); these hazards in cluded both land and marine based pollution sources (e.g. industries, agricultural activities, ports and marinas). We also collected data on oil volumes and types stored at airports, ports, industries, storage sites, oil rigs, maritime traffic, as well as potential exposure of shorelines to a hypothetical worst case oil spill. The latter was assessed through a set of oil spill simulations along the pilot areas' coastlines using the MedSLIK II model (see Al Shami et al., 2017). The simulated oil spill accounted for variations in sea temperature, current velocity and direc tion, wind speed and direction along the Mediterranean coastline (El Fadel et al., 2012; Astiaso et al., 2013b). Oil spill simulation results were used to generate a Shoreline Exposure Index (SEI) that defined both the areas that might be hit most frequently as well as the areas that are exposed to the highest concentrations. HNSI and Shoreline Ex posure Index (SEI) range from 0 to $10^{2}$

For more information on vulnerability and hazard assessment please refer to the Supplementary material.

\subsubsection{Prioritization of the coastline for specific risks}

The vulnerability assessment outcomes were combined with the hazard analyses for the creation of three integrated evaluations that allow to prioritize the coastline for specific risks. To combine vulnerabil ity and hazard indexes without downweighting or upweighting any index, all original indices (BVI, HFI, HNS, SEI and ESI) were rescaled to a common 1 to 5 scale. This procedure can be changed in case the oper ator wishes to give more importance to one of the variables: for exam ple, to assign more importance to the stressor "urban fragmentation" HFI can be used with its original ranges ( 618 ) without rescaling, this giving to this factor more weight on the final prioritization score. Prior itizations were performed according to the two different BVI evaluation and spatial extension: using habitats only (area level, broad extension) and habitat and species (site level, small extension).

2.2.3.1. Prioritization for the risk of fragmentation of natural ecosystems. The HFRI was developed combining the Biodiversity Vulnerability Index (BVI) and the Hazard Fragmentation Index (HFI). Both indices are cell based, hence we simply calculated the final prioritization rank ing for the fragmentation of natural ecosystems combining the indices according to the risk matrix (see Table 1.a and Fig. 2).

\section{HFRI $\quad$ BVI $\times$ HFI}

where HFRI is the Habitat Fragmentation Risk Index, BVI is the Biodiver sity Vulnerability Index and HFI is the Habitat Fragmentation Index at cell level. Note that the Spearman rank correlation was used to quantify the coherence of the results obtained at site vs pilot area level.

\footnotetext{
${ }^{1}$ http://www.enpicbcmed.eu/projects/library-of-deliverables and reports

${ }^{2}$ http://www.greatmed.eu/joomla/component/content/article/reports-96
} 
Table 1

Matrices adopted to prioritize the coastline for specific risks.

\begin{tabular}{|c|c|c|c|c|c|c|}
\hline \multirow[t]{2}{*}{ HFRI or HNSRI } & & \multicolumn{5}{|c|}{ A. Hazard Fragmentation Index (HFI) or HNS/Anthropogenic Hazard Index (HNSI) } \\
\hline & & 1 & 2 & 3 & 4 & 5 \\
\hline \multirow[t]{5}{*}{ Biodiversity Vulnerability Index (BVI) } & 1 & Very Low & Very Low & Low & Low & Medium \\
\hline & 2 & Very Low & Low & Low & Medium & High \\
\hline & 3 & Low & Low & Medium & High & High \\
\hline & 4 & Low & Medium & High & High & Very High \\
\hline & 5 & Medium & High & High & Very High & Very High \\
\hline \multirow[t]{2}{*}{ OSRI } & & \multicolumn{5}{|c|}{ B. Shoreline Exposure Index to Oil (SEI) } \\
\hline & & 1 & 2 & 3 & 4 & 5 \\
\hline \multirow{5}{*}{$\begin{array}{l}\text { Biodiversity Vulnerability Index }(\text { BVI }) \times \text { Environmental Sensitivity } \\
\text { Index (ESI) }\end{array}$} & 1 & Very low & Very low & Low & Low & Medium \\
\hline & 2 & Very low & Low & Low & Medium & High \\
\hline & 3 & Low & Low & Medium & High & High \\
\hline & 4 & Low & Medium & High & High & Very high \\
\hline & 5 & Medium & High & High & Very high & Very high \\
\hline
\end{tabular}

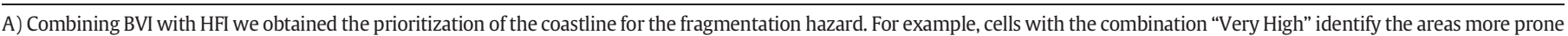

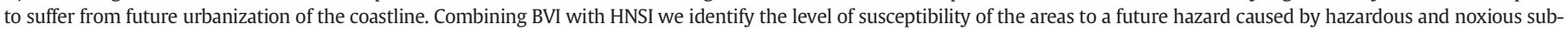
stances (HNS). For oil spill prioritization we adopted a slightly different approach.

B) Taking into account the morphological factors of the coastline (ESI).

2.2.3.2. Prioritization for the risk of anthropogenic, hazardous and noxious substances (HNS). The HNS/Anthropogenic Risk Index (HNSRI) was de veloped combining the Biodiversity Vulnerability Index (BVI) and the HNS/Anthropogenic Hazard Index (HNSI). Using a geo processing in strument, we extracted the overlapping areas of BVI cells and HNSI polygons. HNSRI was calculated by combining the indices according to the risk matrix (see Fig. 2).

HNSRI BVI $\times$ HNSI

2.2.3.3. Prioritization for the risk of an oil spill event. The Shoreline Expo sure Index to Oil (SEI) was integrated with the Biodiversity Vulnerabil ity Index (BVI) and with the Environmental Sensitivity Index (ESI) to develop an overall Oil Spill Risk Index (OSRI), according to the following formula: OSRI $=(\mathrm{BVI} \times \mathrm{ESI}) \times$ SEI.

Overlaying the three data layers, we extracted the overlapping areas and calculated the final OSRI prioritization value (see Table 1.b).

\section{Results}

We produced the prioritization of the coastline for the three hazards analyzed, at site and area level, for the four countries (Fig. 3). ${ }^{3}$ At the pilot area level we analyzed in Italy about $90 \mathrm{~km}$ of coastline, in France $>150 \mathrm{~km}$, about $80 \mathrm{~km}$ in Lebanon and $>254 \mathrm{~km}$ in Tunisia; at the site level, we sampled and analyzed a total of approximately $82 \mathrm{~km}$ of coast line (26 in Italy, 23 in Lebanon, 23 in France and 10 in Tunisia).

Ranking the territory according the risk assessed for each hazard, we obtained different prioritization areas: for example in France the area to be monitored for oil spill hazard does not coincide with the one identi fied as more prone to suffer from future urbanization of the coastline. For the risk prioritization of fragmentation of natural ecosystems, a good correlation was observed among the results obtained at site vs pilot area level (205 cells; Spearman rank correlation, rho 0,74; $\mathrm{p}<0.001)$. The results were perfectly coherent for $72 \%$ of the cells: Leb anon cells were all coherent ( $100 \%$ of consensus), we observed some discrepancies in France (63\% of consensus) and Italy ( $62 \%$ of consensus) while in Tunisia we observed a strong disagreement among the two ranking (consensus only for $21 \%$ of the cells). At the site level, the cells were assessed as more at risk/priority than at the area level for $21 \%$ of the cells and at a lower risk at the site level than at the area level for 7\%.

\footnotetext{
${ }^{3}$ A complete list and downloadable files of the produced maps are available at: http:// www.greatmed.eu/joomla/component/content/article/maps-123
}

The countries exhibited a different distribution of the pilot areas at the different levels of prioritization (see Table 2). For example, with regards to the percentage of cells to be prioritized for plant diversity conservation vs the fragmentation hazard, all countries show values ranging from medium to low, except Lebanon, which was characterized by $>50 \%$ of the cells as "high medium" level (in comparison to other countries accounting for $<30 \%$ ). For HNS, Lebanon and Tunisia showed the highest alert with a significant portion of areas ranked as very high high priority (Tunisia $42 \%$, Lebanon $25 \%$ ) and $<50 \%$ included in the low/very low priority ranking. The prioritization for oil spill consid ered only a strict portion of the coastline but it gave, nevertheless, indi cation for the management of the coastline. In France the priority was lower, but we identified a portion of high priority in the area of Martigues (see Fig. 3a). In Tunisia the results described the pilot area as more in need of attention for oil spill risk ( $41 \%$ for high to medium risk, which was considerably higher than the one estimated for the other countries, i.e. 16\% for Italy, 3\% or less for France and Lebanon).

\section{Discussion}

We presented a methodological framework to identify the locations where plant diversity is more likely to be damaged by the most common human activities along Mediterranean coastal areas (Cuttelod et al., 2008). For this purpose, several topics were considered. To start with, defining the most appropriate scale is critical because ecological bound aries often do not coincide with the administrative ones, rendering the management of the coastline more difficult. Moreover, sampling biolog ical features is expensive and time consuming (Hortal et al., 2015; Marignani et al., 2014); hence the extent of the study area can also be delimited by the sampling effort that can be covered. In this study, we adopted a double spatial scale (extent) and different levels of ecological information (habitats only, and habitats and plant species).

The two scale approach (area vs site scale) permitted us to show that the detailed information on species richness indicators was impor tant especially for areas of specific conservation interest that other land scape indicators may not efficiently reflect. However, we acknowledge that the use of such indicators can be considerably time and money consuming for data collection (Hortal et al., 2015). Our approach shows that in the absence of such detailed indicators the biodiversity vulnerability indicator can still identify reasonably good the vulnerable areas even though the local variability may be disregarded.

For the fragmentation hazard, the results showed a good agreement among site vs pilot area level in most cases, suggesting that in this kind of assessment the greatest part of diversity can be summarized using 
data on habitats. When congruence was not respected, in most cases the prioritization based on more data (habitat and species, site level) com pared to the area based (habitats only) identified a greater number of high medium priority cells. Nevertheless, the Tunisian case suggests that when dealing with a reduced dataset, the correlation among habitats vs habitats and plants is weak and, consequently, the results of the prior itization can lead to a poor instrument for decision making. It is preferable to present prioritization results in the right context, whereby a first survey

\section{a) France}
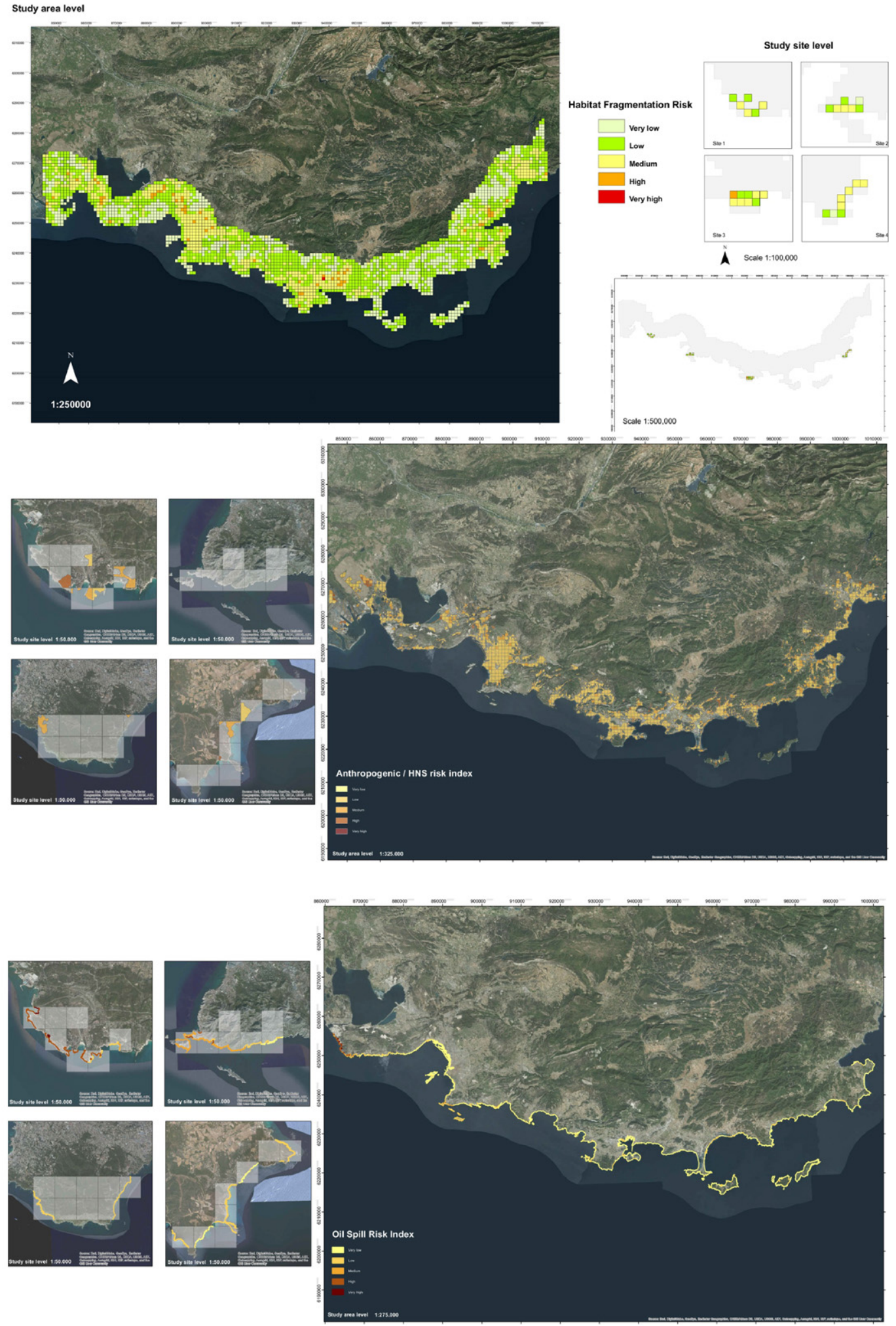

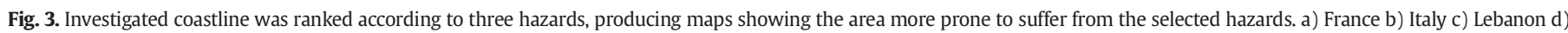
Tunisia. 
b) Italy
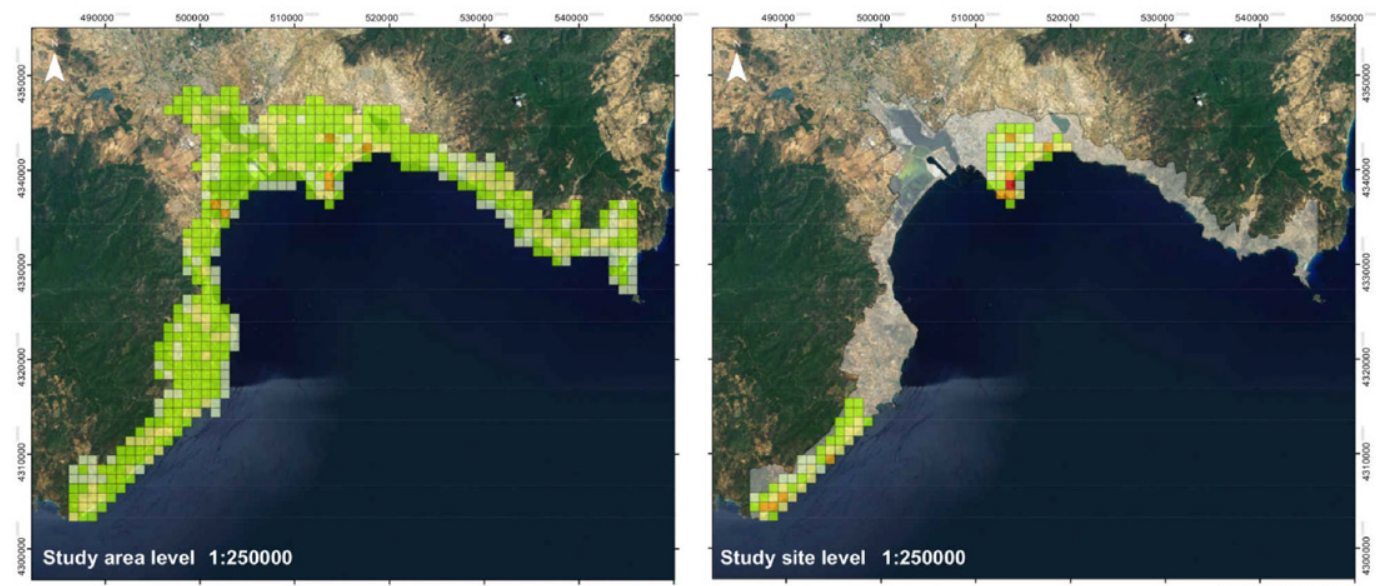

Habitat Fragmentation Risk $\square$ Very low $\square$ Low $\square$ Medium $\square$ High $\square$ Very high
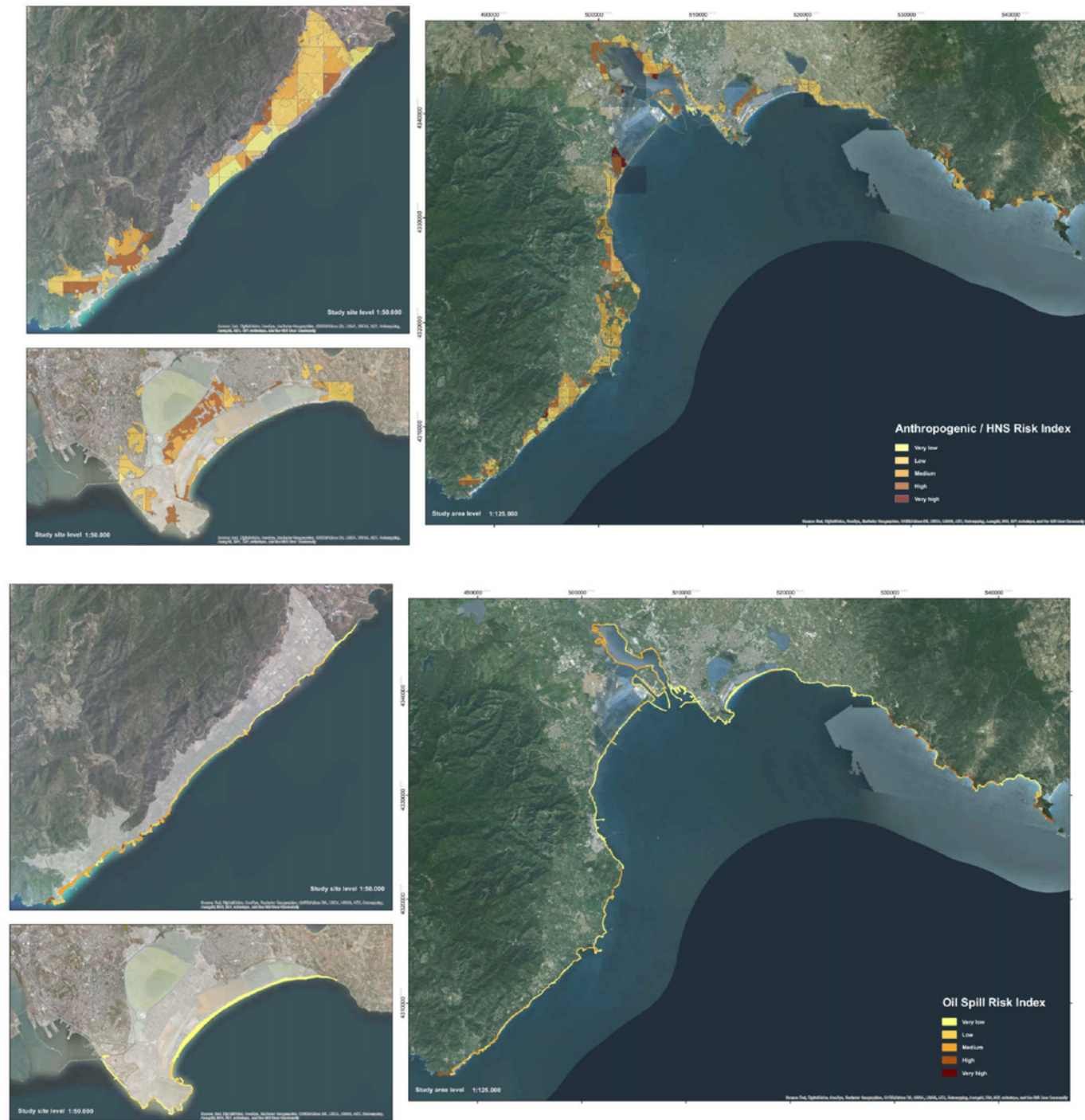

Fig. 3 (continued). 


\section{c) Lebanon}
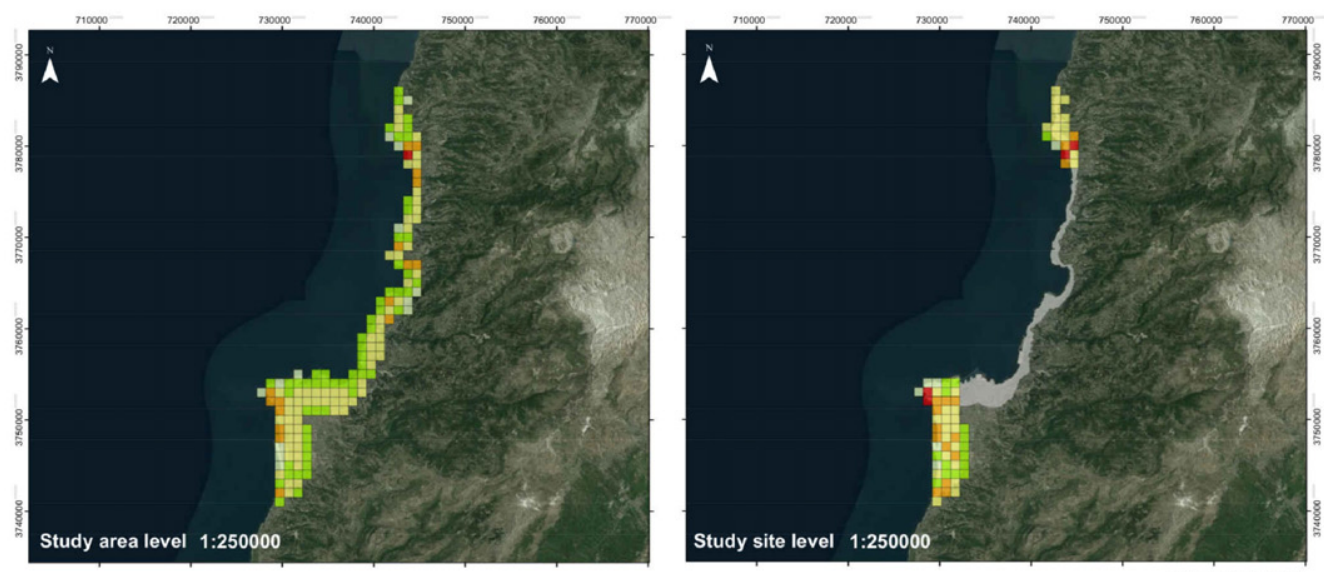

Habitat Fragmentation Risk

ESRI World Imager
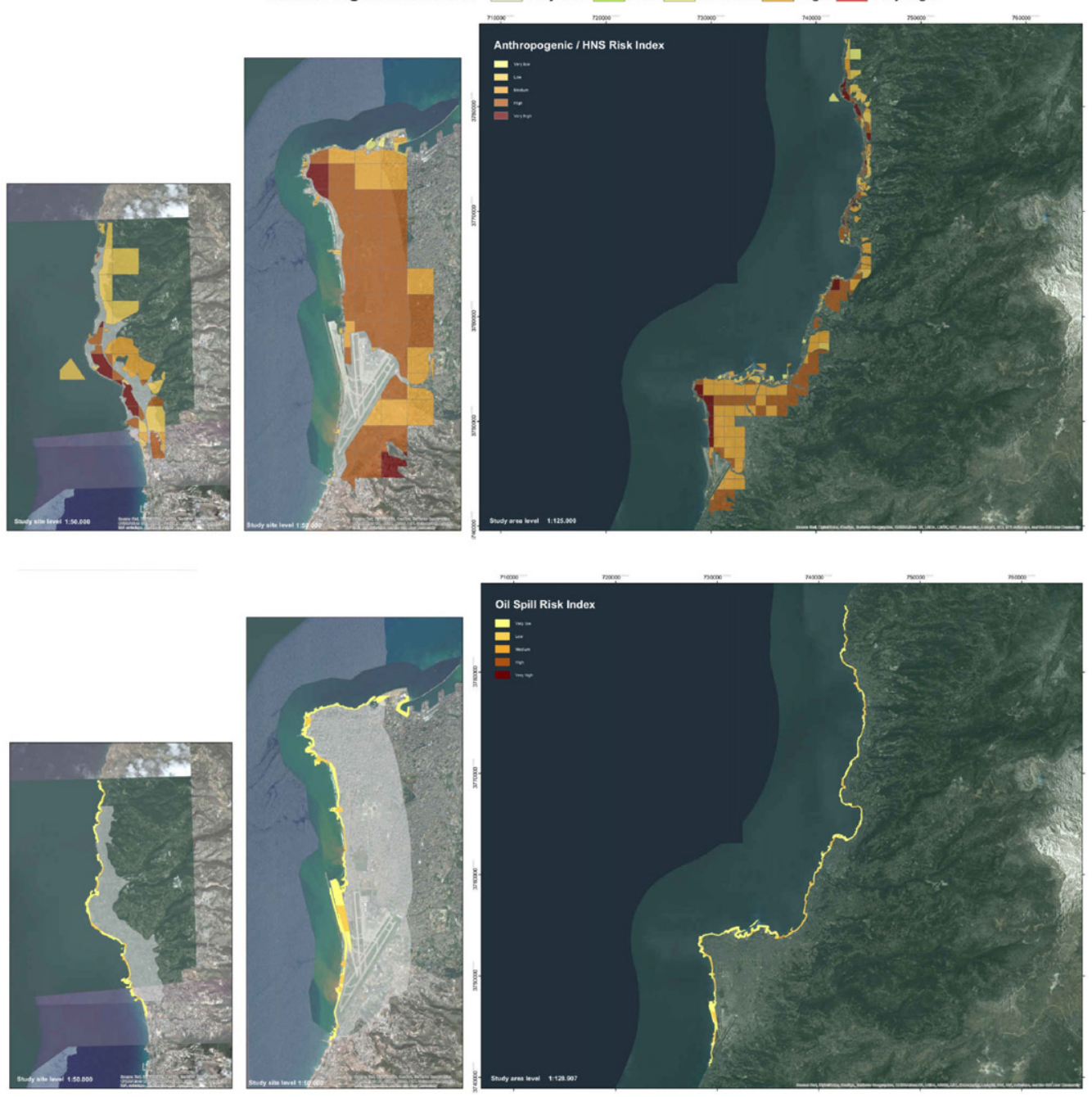

Fig. 3 (continued).

is suggested first on a larger area (e.g. pilot area level) to determine the most important sites at broad scale and then perform a more detailed in vestigation on biological elements in identified critical areas.

Selecting the location where to intervene first represents one of sever al actions that must be taken to preserve the ecological integrity of the Mediterranean coastline. But to prioritize areas according to their environmental risk, we must first assess and then combine ecological and hazard indicators into a repeatable risk assessment procedure. Our approach highlighted the chance to follow a methodology that can be flexible and weigh the different elements composing the procedure ac cording to local needs. The matrices adopted to prioritize the coastline for specific risks can be modified and different weight can be assigned 
d) Tunisia
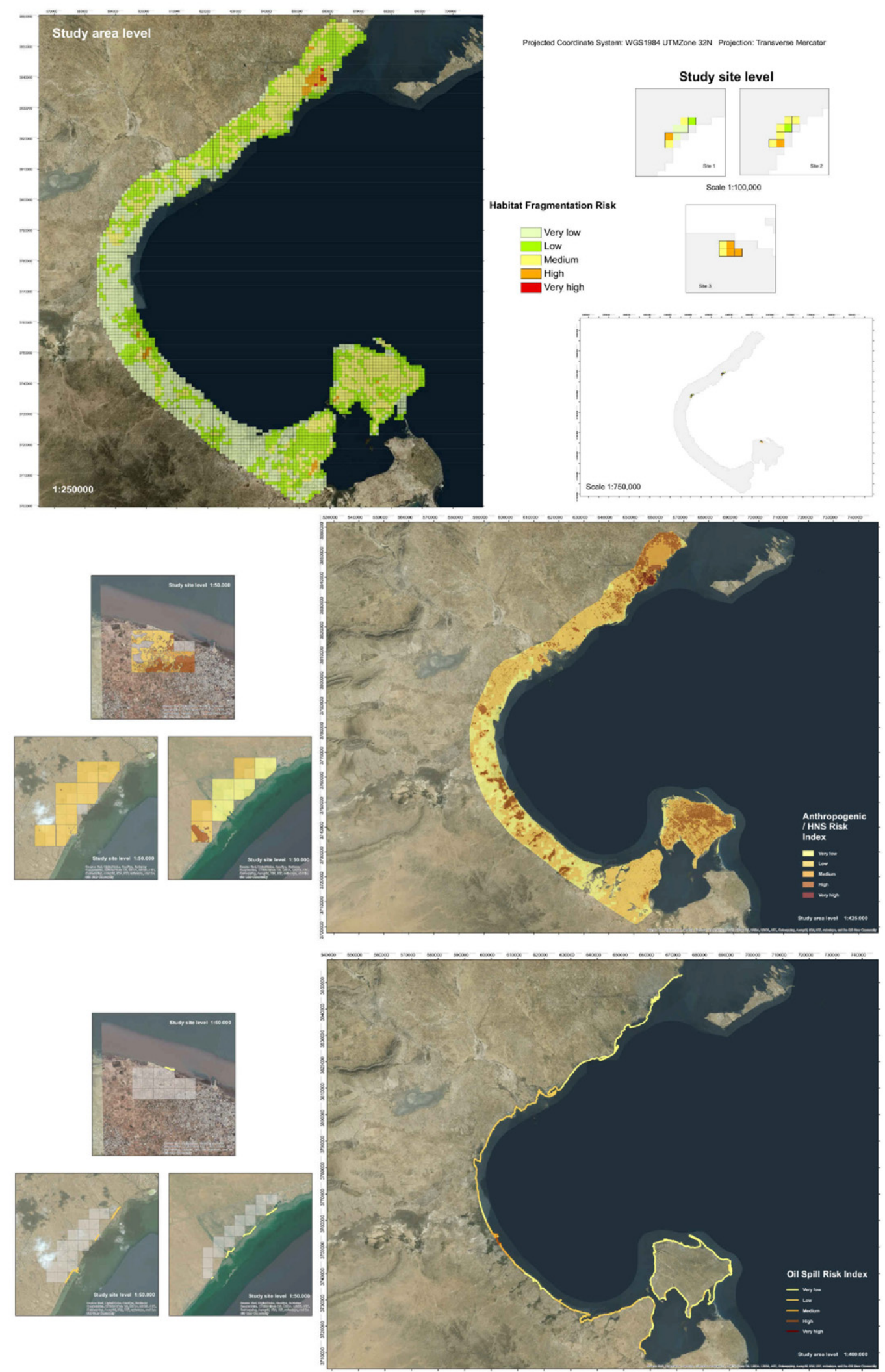

Fig. 3 (continued), 
Table 2

Relative ranking of the coastline according to the three different analyzed hazards: habitat fragmentation, HNS/anthropogenic substances and oil spill (data in percentage, pilot area level).

\begin{tabular}{|c|c|c|c|c|c|}
\hline & Very high & High & Medium & Low & Very low \\
\hline \multicolumn{6}{|c|}{ Habitat fragmentation } \\
\hline France & 0,0 & 2,1 & 22,8 & 47,1 & 28,0 \\
\hline Italy & 0,0 & 1,2 & 17,4 & 62,5 & 18,9 \\
\hline Lebanon & 0,7 & 10,5 & 43,1 & 37,3 & 8,5 \\
\hline Tunisia & 0,1 & 1,7 & 25,8 & 37,7 & 34,7 \\
\hline Mean value & 0,2 & 3,8 & 27,3 & 46,1 & 22,5 \\
\hline \multicolumn{6}{|c|}{ HNS/Anthropogenic substances } \\
\hline France & 0,1 & 6,8 & 27,4 & 65,4 & 0,3 \\
\hline Italy & 1,5 & 17,1 & 18,2 & 40,9 & 22,2 \\
\hline Lebanon & 5,0 & 23,5 & 29,5 & 30,0 & 12,1 \\
\hline Tunisia & 1,2 & 41,5 & 13,5 & 37,9 & 5,8 \\
\hline Mean value & 1,9 & 22,2 & 22,2 & 43,6 & 10,1 \\
\hline \multicolumn{6}{|l|}{ Oil spill } \\
\hline France & 0,8 & 2,0 & 0,9 & 21,7 & 74,5 \\
\hline Italy & 0,1 & 6,7 & 9,6 & 33,1 & 50,4 \\
\hline Lebanon & 0,0 & 0,0 & 1,4 & 41,4 & 57,3 \\
\hline Tunisia & 0,0 & 23,1 & 18,3 & 36,2 & 22,4 \\
\hline Mean value & 0,2 & 8,0 & 7,5 & 33,1 & 51,2 \\
\hline
\end{tabular}

to a specific hazard or to a specific element of the vulnerability (e.g. the presence of endemic species). Investigating three of the most common hazard threatening Mediterranean coastal areas, we could identify dis tinct areas and act properly for the singular examined hazard. For exam ple in the Gulf of Cagliari (Italy) the areas most jeopardized by an Anthropogenic/HNS hazard are scattered along the whole coastline, with a significant part in the Molentargius Park. Oil spill risk is higher in the Western (Chia) and Eastern part of the Gulf (Villasimius) whereas, for urbanization the higher risk is located in the city of Cagliari, surround ing Capo Sant'Elia and the Poetto beach, an area under pressure for tour ism exploitation all year round. When summarizing the three hazards, the Poetto area seems to be the most at risk for multiple hazards, but in a proper planning of risk management the one action fits all approach is not appropriate. Therefore, to be more effective we should focus on the area surrounding Capo Sant'Elia for a strict limitation of urbanization growth, monitor the area of Molentargius for Anthropogenic/HNS hazard and invest in specific emergency planning for the occasional (but danger ous) chance of oil spill in Villasimius and Chia. In our approach, we decid ed to assess risks singularly, to reinforce the message that prioritization is about resource allocation decisions, hence priority setting requires ex plicit and defensible objectives (Brown et al., 2015). In fact, decision sci ence is founded on the concept that to set priorities we must at least define a clear objective and a set of actions, from which a subset will be chosen as priorities (Game et al., 2013). Nevertheless, we acknowledge that a multiple hazard analyses, able to consider the cascading effects in a full multi risk approach (e.g. Gill and Malamud, 2017), could integrate the approach and improve its efficiency.

In the administration of the territory, managers frequently have to deal with multiple priorities and the request for a scientifically sound solution is becoming increasingly pressing (Appelquist and Balstrøm, 2015; Valdor et al., 2016): our flexible method can cope with different stressors (hazards) and can be weighted according to local necessities and specific urgencies. The prioritization, based on the risk assessment, will help in the ordinary and extraordinary management of those areas and assist in defining where and how to intervene in case of emergency. For example, in case of an environmental disaster (i.e. oil spill event), managers and local stakeholders will be better informed on the status of the coastline so to minimize the effect of the disaster and maximize the use of available resources. Ultimately, the adoption of this approach in different countries along with the elaboration of an integrated GIS da tabase will provide comprehensive sensitivity, risk, and hazard layers that can be easily updated and integrated in future monitoring manage ment programs in the Mediterranean Basin.
As for any other methodology, the real efficiency (and relative limi tations) of the method will be tested if it will be applied in other sites, keeping the general approach and modifying, e.g. the weights of the sin gular indexes or the stressors assessed, to adapt it to the specific local needs and verify its potentiality of flexibility and adaptability. For exam ple, we could have investigated more deeply the influence of agricultur al activities (fertilizers and/or agrochemicals), but in the involved countries agricultural activities have different forms and different influ ence on biodiversity. In Tunisia for example, the presence of agricultural areas have a great impact on the coastal aquifer and salt habitats consid ered in the study (El Ayni et al. 2012), in France the majority of agricul tural areas in the gulf of Marseille consists in traditional agricultural landscapes, which have an important role for the conservation of the plant species; in Italy the situation is in between (Tieskens et al. 2017). Moreover, except for Lebanon, we could not gather any informa tion on the quantity and quality of the fertilizers and agrochemicals used in the agricultural areas. Nevertheless, we chose to include agricul tural pollution in the Anthropogenic hazard to maintain the possibility to include this type of stressor in the proposed approach.

We believe that the analyzed case studies represent a good range of the different situation we can find in the Mediterranean basin but, at the same time, we acknowledge that the application of the method in other Mediterranean countries could highlight the limitations and the possi ble future improvements of the method. These improvements could come not only from the application in other geographically distinct sit uations, but more interestingly in the implementation of the method in prioritizing the landscape for other stressors such as invasive alien spe cies or increasing sea level rise.

\section{Conclusions}

Coastal management in the Mediterranean is an important issue for the conservation of biodiversity and cultural heritage, and represents a chance for the sustainable use of resources. We proposed an integrated transdisciplinary method that incorporates technical and scientific disci plines combining an engineering approach to the problem of risk indices development (based on maritime traffic, morphological and hydrody namic factors) with an ecological approach that considers the value of plant diversity at species and habitat level in a highly biodiverse, but in creasingly stressed, system such as the Mediterranean basin. Neverthe less, transdisciplinarity does not directly ensure management success, which depends also on the complexity of the problem and the difficulties to find compromises between protection and conservation goals on one hand, and socio economic development on the other.

The proposed approach can help in providing solutions to face com mon threats and pressures across the Mediterranean Basin in a more comprehensive way. Its generality and transferability, provides a com mon sampling strategy for biodiversity assessment, a set of criteria for prioritizing sites based on biodiversity, and protocols and equations to generate maps of environmental vulnerability and evaluate hazards and priorities. As such, the approach has the potential to become a stan dard framework for monitoring and assessment of projects in coastal re gions for the entire Mediterranean Basin.

It can provide public administrations and local communities an easy to use instrument towards ICZM and preventing and managing unfore seen spills of hydrocarbons or other stressor menacing biodiversity, cul tural heritage or other valuable elements to be protected. We believe that building a cross border network where all partners meet to share needs, objectives, expertise and results is crucial to converge towards a single strategy that has the potential to be extended to other coastal Mediterranean areas.

\section{Funding}

The GREAT Med project was financed by the European Union (ENPI CBC Mediterranean Sea Basin Programme) through the European 
Neighborhood and Partnership Instrument. Its Grant Agreement is no. $39 / 2377$.

\section{Acknowledgments}

We wish to thank Chiara D'Angeli for GIS and technical support; Mauro Fois and Selena Puddu for data and field work assistance; Claudia Cogoni for administrative and logistic assistance; Gianluigi Bacchetta for valuable suggestions during the project; Regione Sardegna Assessorato della difesa dell'Ambiente (Servizio sostenibilità ambientale e Sistemi informativi; Servizio Tutela della natura e politiche forestali) for kindly providing the habitat maps of Natura 2000 sites for the Italian study area; the Conservatoire Botanique National Méditerranéen (Hyères, France) and Virgile Noble for extracting data from the SILENE database and Pierre Jean Dumas for providing coastline data.

\section{Appendix A. Supplementary data}

Supplementary data to this article can be found online at http://dx. doi.org/10.1016/j.scitotenv.2017.02.221.

\section{References}

Abdulla, A., Linden, O. (Eds.), 2008. Maritime traffic effects on biodiversity in the Mediterranean Sea: Review of impacts, priority areas and mitigation measures. IUCN Centre for Mediterranean Cooperation, Malaga, Spain.

Al Shami, A., Harik, G., Alameddine, I., Bruschi, D., Astiaso, Garcia D., El-Fadel, M., 2017. Risk assessment of oil spills along the Mediterranean coast: a sensitivity analysis of the choice of hazard quantification. Sci. Total Environ. 574, 234-245.

Appelquist, L.R., Balstrøm, T., 2015. Application of a new methodology for coastal multihazard-assessment \& management on the state of Karnataka, India. J. Environ. Manag. 152, 1-10.

Arkema, K.K., Guannel, G., Verutes, G., Wood, S.A., Guerry, A., Ruckelshaus, M., Kareiva, P., Lacayo, M., Silver, J.M., 2013. Coastal habitats shield people and property from sealevel rise and storms. Nat. Clim. Chang. 3, 913-918.

Astiaso Garcia, D., Cumo, F., Gugliermetti, F., Rosa, F., 2013c. Hazardous and noxious substances (HNS) risk assessment along the Italian coastline. Chem. Eng. Trans. 32, 115-120.

Astiaso, Garcia D., Bruschi, D., Cinquepalmi, F., Cumo, F., 2013a. An estimation of urban fragmentation of natural habitats: case studies of the 24 Italian national parks. Chem. Eng. Trans. 32, 49-54.

Astiaso, Garcia D., Bruschi, D., Cumo, F., Gugliermetti, F., 2013b. The oil spill hazard index (OSHI) elaboration. An oil spill hazard assessment concerning Italian hydrocarbons maritime traffic. Ocean Coast. Manag. 80, 1-11.

Bazairi, H., Ben, Haj S., Boero, F., Cebrian, D., De Juan, S., Limam, A., Lleonart, J., Torchia, G. Rais, C. (Eds.), 2010. The Mediterranean Sea Biodiversity: State of the Ecosystems, Pressures, Impacts and Future Priorities. RAC/SPA, Tunis.

Benoit, G., Comeau, A., 2005. A Sustainable Future for the Mediterranean: The Blue Plan's Environment and Development Outlook. Earthscan Pubns Ltd., London.

Blasi, C., Marignani, M., Copiz, R., Fipaldini, M., Bonacquisti, S., Del Vico, E., Rosati, L. Zavattero, L., 2011. Important plant areas in Italy: from data to mapping. Biol. Conserv. 144, 220-226.

Brown, C.J., Bode, M., Venter, O., Barnes, M.D., McGowan, J., Runge, C.A., Watson, J.E.M. Possingham, H.P., 2015. Effective conservation requires clear objectives and prioritizing actions, not places or species. Proc. Natl. Acad. Sci. U. S. A. 112 (32), E4342. http:// dx.doi.org/10.1073/pnas.1509189112.

Buono, F., Soriani, S., Camuffo, M., Tonino, M. Bordin, A, 2015. The difficult road to Integrated Coastal Zone Management implementation in Italy: evidences from the Italian North Adriatic regions. Ocean Coast. Manag. 114, 21-31.

Celesti-Grapow, L., Alessandrini, A., Arrigoni, P.V., Banfi, E., Bernardo, L., Bovio, M., Brundu, G., Cagiotti, M.R., Camarda, I., et al., 2009. Inventory of the non-native flora of Italy. Plant Biosyst. 143 (2), 386-430.

Celesti-Grapow, L., Alessandrini, A., Arrigoni, P.V., Assini, S., Banfi, E., Barni, E., Bovio, M. Brundu, G., et al., 2010. Nonnative flora of Italy: distribution and threats. Plant Biosyst. $144,12-28$.

Coll, M., Piroddi, C., Steenbeek, J., Kaschner, K., Lasram, F.B.R., Aguzzi, J., Ballesteros, E. Bianchi, C.N., Corbera, J., et al., 2010. The biodiversity of the Mediterranean Sea: estimates, patterns, and threats. PLoS One 5 (8), e11842.

Coudert, E., Larid, M., 2006. IMAGINE: un ensemble de méthodes et d'outils pour contribuer à la gestion intégrée des zones côtières en Méditerranée. VertigO - la revue électronique en sciences de l'environnement (3). http://vertigo.revues.org/ 9059 http://dx.doi.org/10.4000/vertigo.9059.

Cózar, A., Sanz-Martín, M., Martí, E., González-Gordillo, J.I., Ubeda, B., Gálvez, J.Á., Irigoien, X., Duarte, C.M., 2015. Plastic accumulation in the Mediterranean Sea. PLoS One 10, e0121762.

Cuttelod, A., García, N., Abdul, Malak D., Temple, H., Katariya, V., 2008. In: Vié, J.C., HiltonTaylor, C., Gland, S.N. (Eds.), The Mediterranean: A Biodiversity Hotspot Under Threat. In the 2008 Review of The IUCN Red List of Threatened Species. IUCN Switzerland.
De Lange, H.J., Sala, S., Vighi, M., Faber, J.H., 2010. Ecological vulnerability in risk assessment - a review and perspectives. Sci. Total Environ. 408, 3871-3879.

El Ayni, F., Cherif, S., Jrad, A., Trabelsi-Ayadi, M., 2012. A new approach for the assessment of groundwater quality and its suitability for irrigation: a case study of the Korba coastal aquifer (Tunisia, Africa). Water Environ. Res. 84 (8), 673-681.

El-Fadel, M., Abdallah, R., Rachid, G., 2012. A modeling approach toward oil spill management along the Eastern Mediterranean. J. Environ. Manag. 113, 93-102.

European Environment Agency, 2013. Balancing the Future of Europe's Coasts - Knowledge Base for Integrated Management. http://www.eea.europa.eu/publications/ balancing-the-future-of-europes (accessed December, 2016).

European Maritime Safety Agency, 2013. Inventory of EU Member States Policies and Operational Response Capacities for HNS Marine Pollution. http://www.emsa.europa. eu/news-a-press-centre/external-news/2-news/1747-inventory-of-eu-memberstates-policies-and-operational-response-capacities-for-hns-marine-pollution-2013. html (accessed December, 2016).

Frondoni, R., Mollo, B., Capotorti, G., 2011. A landscape analysis of land cover change in the municipality of Rome (Italy): spatio-temporal characteristics and ecological implications of land cover transitions from 1954 to 2001. Landsc. Urban Plan. 100, 117-128.

Füssel, H.M., 2007. Vulnerability: a generally applicable conceptual framework for climate change research. Glob. Environ. Chang. 17, 155-167.

Game, E.T., Kareiva, P., Possingham, H.P., 2013. Six common mistakes in conservation priority setting. Conserv. Biol. 27 (3), 480-485.

Gauthier, P., Debussche, M., Thompson, J.D., 2010. Regional priority setting for rare species based on a method combining three criteria. Biol. Conserv. 143, 1501-1509.

Gill, J.C., Malamud, B.D., 2017. Anthropogenic processes, natural hazards, and interactions in a multi-hazard framework. Earth Sci. Rev. 166, 246-269.

Halpern, B.S., Walbridge, S., Selkoe, K.A., Kappel, C.V., Micheli, F., D'Agrosa, C., Bruno, J.F., Casey, K.S., Ebert, C., Fox, H.E., Fujita, R., Heinemann, D., Lenihan, H.S., Madin, E.M., Perry, M.T., Selig, E.R., Spalding, M., Steneck, R., Watson, R., 2008. A global map of human impact on marine ecosystems. Science 319 (5865), 948-952.

Harold, P.D., de Souza, A.S., Louchart, P., Russell, D., Brunt, H., 2014. Development of a riskbased prioritisation methodology to inform public health emergency planning and preparedness in case of accidental spill at sea of hazardous and noxious substances (HNS). Environ. Int. 72, 157-163.

Hejda, M., Pyšek, P., Jarošík, V., 2009. Impact of invasive plants on the species richness, diversity and composition of invaded communities. J. Ecol. 97 (3), 393-403.

Hortal, J., de Bello, F., Diniz-Filho, J.A.F., Lewinsohn, T.M., Lobo, J.M., Richard Ladle, R.J., 2015. Seven shortfalls that beset large-scale knowledge of biodiversity. Annu. Rev. Ecol. Evol. Syst. 46, 523-549.

Hubbard, D., Evans, D., 2010. Problems with scoring methods and ordinal scales in risk assessment. IBM J. Res. Dev. 54, 246-255.

IUCN, 2016. The IUCN Red List of Threatened Species. Version 2016-3. http://www. iucnredlist.org (accessed December, 2016).

Jackson, M.C., 2006. Creative holism: a critical systems approach to complex problem situations. Syst. Res. Behav. Sci. 23, 647-657.

Kamphuis, J.W., 2011. Coastal project management. Coast. Manag. 39, 72-81.

Komendantova, N., Mrzyglocki, R., Mignan, A., Khazai, B., Wenzel, F., Patt, A., Fleming, K., 2014. Multi-hazard and multi-risk decision-support tools as a part of participatory risk governance: feedback from civil protection stakeholders. Int. J. Disaster Risk Reduct. 8, 50-67.

Kukkala, A.S., Moilanen, A., 2013. Core concepts of spatial prioritisation in systematic conservation planning. Biol. Rev. Camb. Philos. Soc. 88 (2), 443-464.

Lejeusne, C., Chevaldonne, P., Pergent-Martini, C., Boudouresque, C.F., Perez, T., 2010. Climate change effects on a miniature ocean: the highly diverse, highly impacted Mediterranean Sea. Trends Ecol. Evol. 25 (4), 250-260.

Levin, S.A., 1992. The problem of pattern and scale in ecology: the Robert H. MacArthur Award Lecture. Ecology 73, 1943-1967.

Lhotte, A., Affre, L., Saatkamp, A., 2014. Are there contrasted impacts of urbanization and land uses on population persistence? The case of Teucrium pseudochamaepitys, an endangered species in Southern France. Flora 209 (9), 484-490.

Mack, R.N., Simberloff, D., Lonsdale, W.M., Evans, H., Clout, M., Bazzaz, F.A., 2000. Biotic invasions: causes, epidemiology, global consequences, and control. Ecol. Appl. 10, 689-710.

Malavasi, M., Santoro, R., Cutini, M., Acosta, A.T.R., Carranza, M.L., 2014. The impact of human pressure on landscape patterns and plant species richness in Mediterranean coastal dunes. Plant Biosyst. 150, 73-82.

Marignani, M., Bacchetta, G., Bagella, S., Caria, M.C., Delogu, F., Farris, E., Fenu, G., Filigheddu, R., Blasi, C., 2014. Is time on our side? Strengthening the link between field efforts and conservation needs. Biodivers. Conserv. 23 (2), 421-431.

McGarigal, K., Neel, M.C., Ene, E., 2002. FRAGSTATS: Spatial Pattern Analysis Program for Categorical Maps. http://www.umass.edu/landeco/research/fragstats/fragstats.html (accessed December, 2016).

Medail, F., Quezel, P., 1999. Biodiversity hotspots in the Mediterranean Basin: setting global conservation priorities. Conserv. Biol. 13, 1510-1513.

Mittermeier, R.A., Gil, P.B., Hoffman, M., Pilgrim, J., Brooks, T., Goettsch, Mittermeier C., Lamoreux, J., da Fonseca, G.A.B., 2005. Hotspots Revisited. 392 pp. University of Chicago Press, Chicago USA (ISBN: 9789686397772).

Myers, N., Mittermeier, R.A., Mittermeier, C.G., Da Fonseca, G.A.B., Kent, J., 2000. Biodiversity hotspots for conservation priorities. Nature 403, 853-858.

National Geomatics Center of China, 2014. GLOBELAND30. http://www.globallandcover. com (accessed July 21, 2015).

NOAA, 2002. Environmental Sensitivity Index Guidelines. Version 3.0. http://response. restoration.noaa.gov (accessed December, 2016)

Norton, L., Greene, S., Scholefield, P., Dunbar, M., 2016. The importance of scale in the development of ecosystem service indicators? Ecol. Indic. 61 (2016), 130-140. 
Olson, D.M., Dinerstein, E., 1998. The Global 200: a representation approach to conserving the Earth's most biologically valuable ecoregions. Conserv. Biol. 12 (3), 502-515.

Prem, M., 2010. Implementation obstacles of the ICZM protocol and mitigation efforts. J. Coast. Conserv. 14, 257-264.

Pressey, R.L., Humphries, C.J., Margules, C.R., Vane-Wright, R.I., Williams, P.H., 1993. Beyond opportunism: key principles for systematic reserve selection. Trends Ecol. Evol. 8 (4), 124-128.

Pyšek, P., Richardson, D.M., Rejmánek, M., Webster, G.L., Williamson, M., Kirschner, J. 2004. Alien plants in checklist and floras: towards better communication between taxonomists and ecologists. Taxon 53 (1), 131-143.

Pyšek, P., Jarošík, V., Chytrý, M., Kropáč, Z., Tichý, L., Wild, J., 2005. Alien plants in temperate weed communities: prehistoric and recent invaders occupy different habitats. Ecology 86, 772-785.

Reyers, B., Roux, D.J., Cowling, R.M., Ginsburg, A.E., Nel, J.L., Farrell, P.O., 2010. Conservation planning as a transdisciplinary process. Conserv. Biol. 24, 957-965.

Rossi, G., Montagnani, C., Abeli, T., Gargano, D., Peruzzi, L., Fenu, G., et al., 2013. Are Red Lists really useful for plant conservation? The new Red List of the Italian Flora in the perspective of National Conservation policies. Plant Biosyst. 148 (2), 1-4.

Seebens, H., Blackburn, T.M., Dyer, E.E., Genovesi, P., Hulme, P.E., Jeschke, J.M., Pagad, Shyama, Pyšek, P., Winter, M., Arianoutsou, M., Bacher, S., Blasius, B., Brundu, G., Capinha, C., Celesti-Grapow, L., Dawson, W., Dullinger, S., Fuentes, N., Jäger, H.,
Kartesz, J., Kenis, M., Kreft, H., Kühn, I., Lenzner, B., Liebhold, A., Mosena, A., Moser D., Nishino, M., Pearman, D., Pergl, J., Rabitsch, W., Rojas-Sandoval, J., Roques, A., Rorke, S., Rossinelli, S., Roy, H.E., Scalera, R., Schindler, S., Štajerová, K., TokarskaGuzik, B., van Kleunen, M., Walker, K., Weigelt, P., Yamanaka, T., Essl, F., 2017. No saturation in the accumulation of alien species worldwide. Nat. Commun. 8, 14435.

Stock, P., Burton, R.J.F., 2011. Defining terms for integrated (multi-inter-trans-disciplinary) sustainability research. Sustainability 3 (8), 1090-1113.

Thompson, J.D., 2005. Plant Evolution in the Mediterranean. Oxford University Press, Oxford, UK.

Tieskens, K.F., Schulp, C.J.E., Levers, C., Lieskovský, J., Kuemmerle, T., Plieninger, T., Verburg, P.H., 2017. Characterizing European cultural landscapes: accounting for structure, management intensity and value of agricultural and forest landscapes. Land Use Policy 62, 29-39.

Valdor, P.F., Gómez, A.G., Ondiviela, B., Puente, A., Juanes, J.A., 2016. Prioritization maps: the integration of environmental risks to manage water quality in harbor areas. Mar. Pollut. Bull. 111 (1-2), 57-67.

Wamsley, T.V., Collier, Z.A., Brodie, K., Dunkin, L.M., Raff, D., Rosati, J.D., 2015. Guidance for developing coastal vulnerability metrics. J. Coast. Res. 31 (6), 1521-1530.

Wilson, K.A., McBride, M.F., Bode, M., Possingham, H.P., 2006. Prioritizing global conservation efforts. Nature 440, 337-340. 